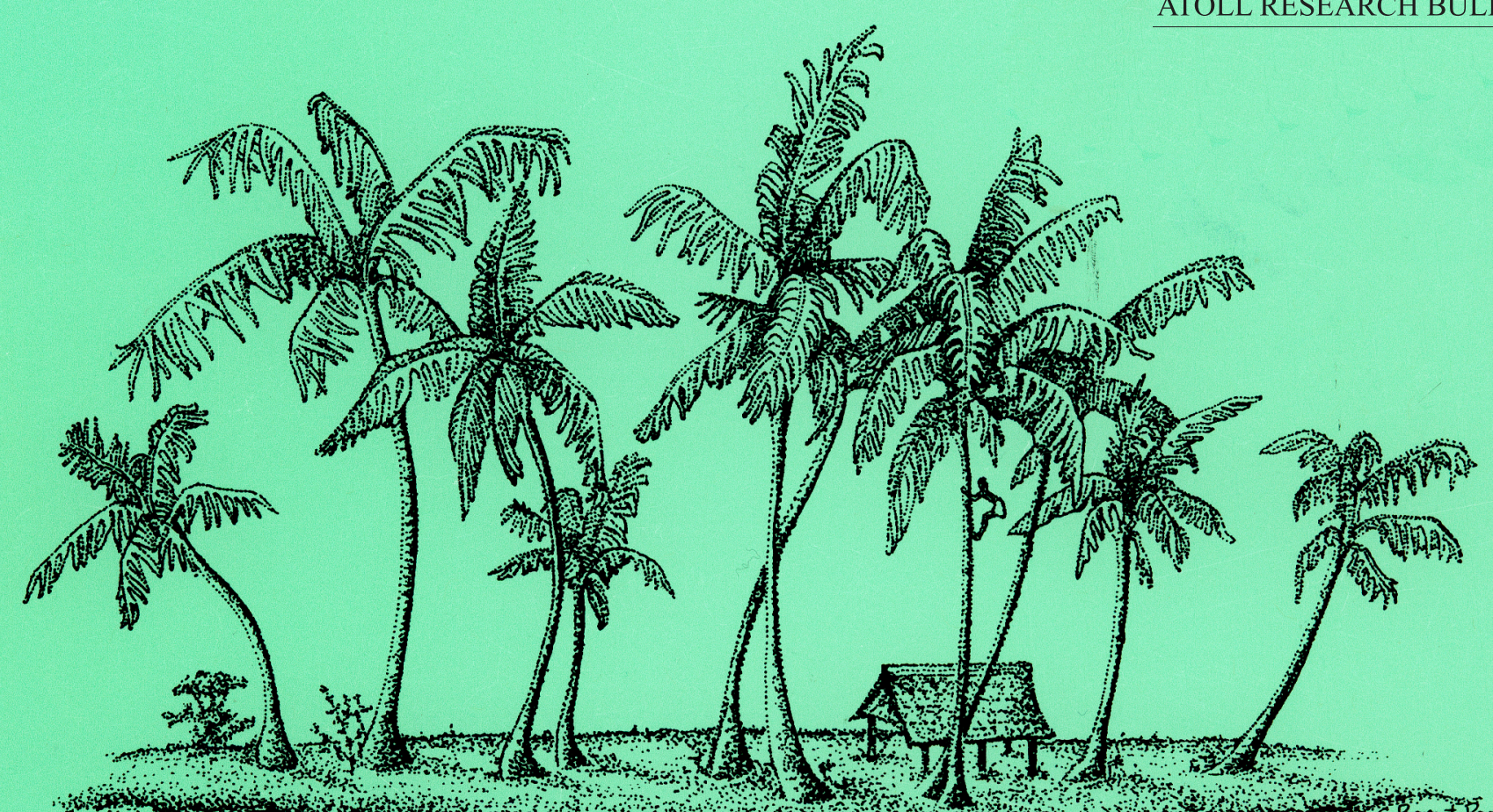

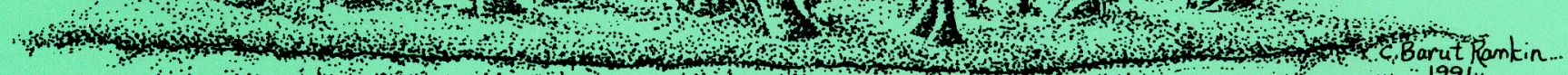

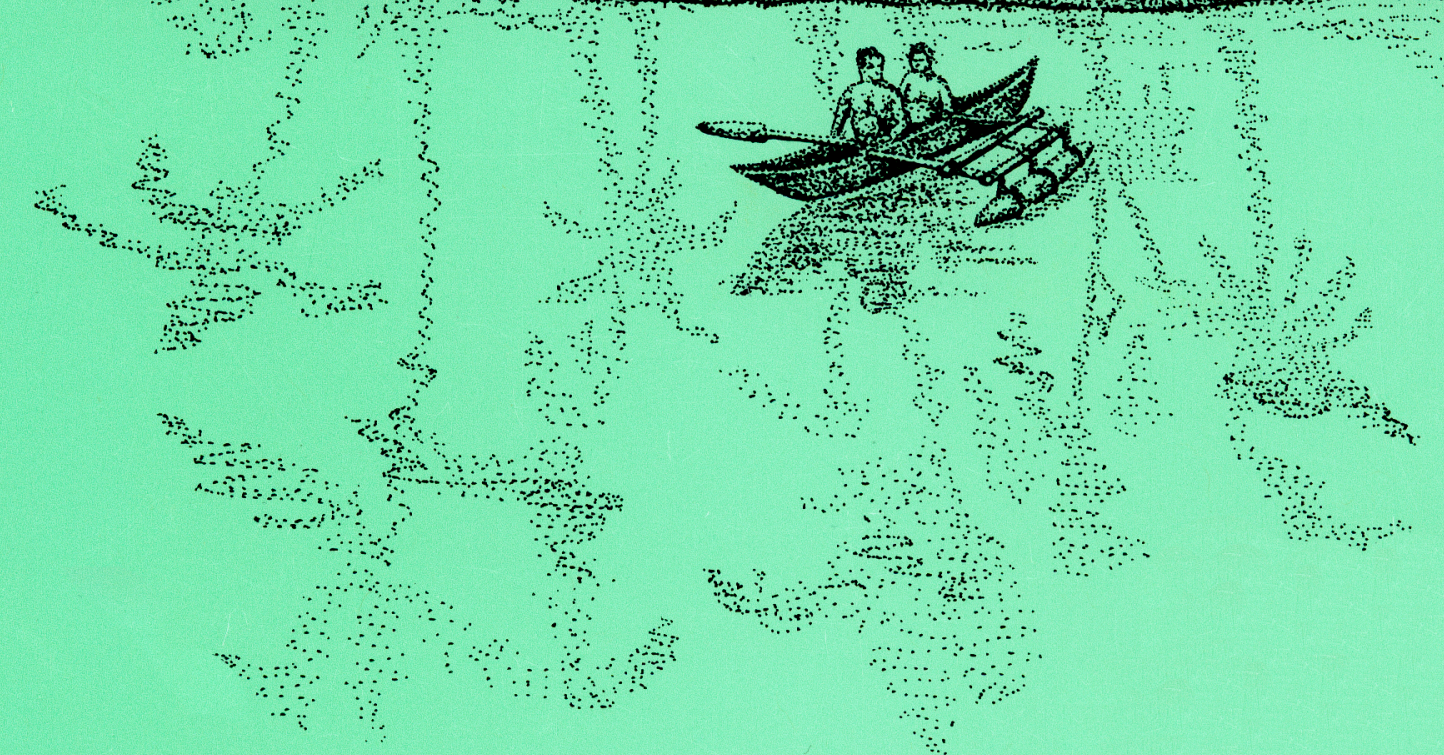

A STATUS REPORT ON THE CORAL REEF AT PULAU DURAI, ANAMBAS ISLANDS, INDONESIA

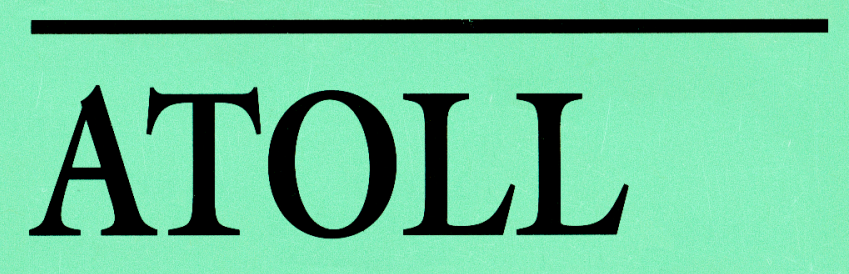

Carol Milner, Katharine Currier, Blake Kopcho, and Abigail Alling

RESEARCH

Smithsonian Institution
Scholarly Press

BULLETIN 


\section{A STATUS REPORT ON THE CORAL REEF AT PULAU DURAI, ANAMBAS ISLANDS, INDONESIA}

Carol Milner, Katharine Currier, Blake Kopcho and Abigail Alling

Atoll Research Bulletin No. 591 23 October 2013

Smithsonian Institution

Scholarly Press 
All statements made in papers published in the Atoll Research Bulletin are the sole responsibility of the authors and do not necessarily represent the views of the Smithsonian Institution or of the editors of the Bulletin. Articles submitted for publication in the Atoll Research Bulletin should be original papers and must be made available by authors for open access publication. Manuscripts should be consistent with the "Author Formatting Guidelines for Publication in the Atoll Research Bulletin." All submissions to the Bulletin are peer reviewed and, after revision, are evaluated prior to acceptance and publication through the publisher's open access portal, Open SI (http://opensi.si.edu).

Published by SMITHSONIAN INSTITUTION SCHOLARLY PRESS

P.O. Box 37012, MRC 957

Washington, D.C. 20013-7012

www.scholarlypress.si.edu

The rights to all text and images in this publication are owned either by the contributing authors or third parties. Fair use of materials is permitted for personal, educational, or noncommercial purposes. Users must cite author and source of content, must not alter or modify the content, and must comply with all other terms or restrictions that may be applicable. Users are responsible for securing permission from a rights holder for any other use.

ISSN: 0077-5630 (online) 


\title{
A STATUS REPORT ON THE CORAL REEF AT PULAU DURAI, ANAMBAS ISLANDS, INDONESIA
}

\author{
BY \\ CAROL MILNER $^{1}$, KATHARINE CURRIER $^{1,2}$, BLAKE KOPCHO $^{1}$ \\ and ABIGAIL ALLING ${ }^{1}$
}

\begin{abstract}
The coral reefs surrounding Pulau Durai (located in the northwest of Indonesia in the Anambas Islands, South China Sea) were surveyed from 22 June to 5 July 2011 to provide baseline data on their biotic composition and condition. At each of four sites around the island, point intercept methodology over two $50 \mathrm{~m}$ transects yielded an average benthic cover of $26 \%$ live hard coral. The maximum live hard coral cover observed was $47 \%$ on the northern side of the island where fishing boats anchor overnight to seek shelter from the southwest monsoon. The minimum of 3\% live hard coral was observed on the west side, which is the inhabited area of the island and where there is the greatest amount of anthropogenic activity. A total of 38 hard coral genera and 115 fish species were recorded across all transects. The average biomass of fish per transect was $2135.5 \mathrm{~kg} / \mathrm{ha}$ and the populations were mostly comprised of herbivores which correlated with the abundance of dead coral, algae overgrowth, and lack of predator fish. Crown-of-thorns starfish (Acanthaster planci) were present at all sites with a maximum of 15 individuals sighted on both the North Shallow and South Shallow transects.

In general, damage from anchors and destructive fishing practices have gravely impacted Pulau Durai's reefs in the past. Present threats include continued anchoring, over-fishing and a current infestation of crown-of-thorns starfish, which are negatively affecting the remaining health and abundance of living coral. Pulau Durai and its neighbouring island, Pulau Pahat, were declared a marine protected area in July 2011. Given the depleted state of this reef, it will be imperative to establish a "no-take" fishing area to restore the fish populations, ban anchoring on the reef to stop the destruction of coral, and if possible, remove the crown-of-thorns starfish.
\end{abstract}

\section{INTRODUCTION}

Anambas Islands. The Anambas Islands are located in the north west of Indonesia approximately $240 \mathrm{~km}$ northeast of Singapore (Fig. 1). The archipelago was formerly administrated under the Riau Islands Regency, but is now independent and undergoing

${ }^{1}$ Biosphere Foundation, P.O. Box 808, Big Pine, CA 93513, USA.

2 Department of Geography, University of California, 1832 Ellison Hall, Santa Barbara, CA 93106-4060, USA. 
rapid development and immigration from people elsewhere in Indonesia such as Jakarta. Additionally, the government of the Anambas Islands is now actively seeking investors to develop the islands for ecotourism and other revenue-generating activities (Qadar, 2010).

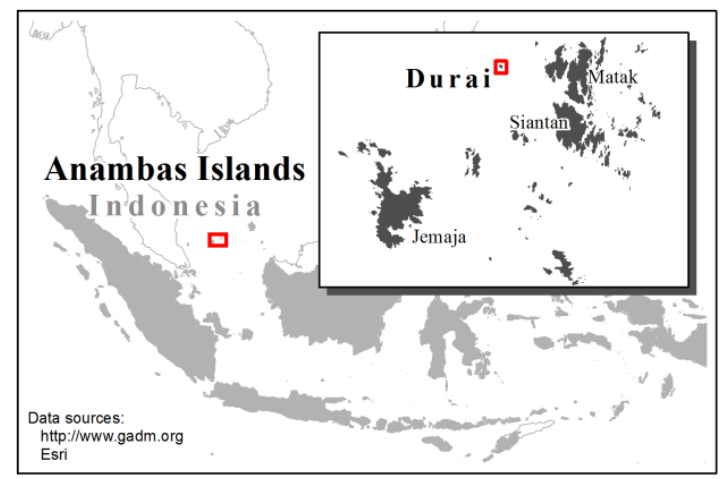

Figure 1. Location of Pulau Durai within the Anambas Islands, Indonesia.

Although the islands lie on the outskirts of the designated "Coral Triangle," this marine landscape has significant potential to harbor a high diversity of reef building corals and associated marine life. However, like all areas within the South China Sea, these reefs face a myriad of challenges from developing nations such as overharvesting of resources, destructive fishing practices, anchor damage to reef corals, susceptibility to coral bleaching, abundant plastic pollution and a rapidly increasing human population. To our knowledge there have been only three recent scientific expeditions to the archipelago documenting the composition and condition of the reefs in the Anambas Islands. These include:

- $\quad 1996$, scientists from the National University of Singapore conducted an initial biological survey of the reefs of Pulau Langor, located northwest of Pulau Matak (Reef Ecology Study Team, 1996). They found live coral cover ranging from 56 to 67 percent and less than 10 percent dead coral cover across three sites around the island. They noted old evidence of dynamite fishing and the conspicuous absence of groupers (Serranidae) and snappers (Lutjanidae) from the reef.

2002, an expedition of scientists from the South China Sea region conducted studies to assess the marine biodiversity of the Anambas and Natuna Islands (Ng et al. 2004a). Their expedition collected around $300 \mathrm{~kg}$ of biological specimens from sixty sites, documented twenty seven new species records for the South China Sea, and resulted in the discovery of five new species. A supplement of the Raffles Bulletin of Zoology documents the findings of the expedition in 13 papers ( $\mathrm{Ng}$ et al. 2004b).

- 2006, a report issued by Biosphere Foundation's "Planetary Coral Reef Expedition" (Doherty, 2006) details an exploratory expedition to five sites in the Anambas Islands from 27 November to 11 December 2006 in which three of the authors of the current paper participated. The presence of crown-of-thorns starfish (Acanthaster planci; COT) was noted as well as old evidence of dynamite fishing and anchor damage to the reefs at several sites. 
Pulau Durai. In 2009, Biosphere Foundation returned to the Anambas Islands and initiated a project to protect Pulau Durai's sea turtle nesting beaches along with Ibu Nina Marliana of Premier Oil and Pak Lahanie, the caretaker of Pulau Durai. Pulau Durai is a small ( 0.9 ha) and relatively remote (12 $\mathrm{nm}$ from the nearest harbor) island located in the northern part of the Anambas Islands (Fig 1). It is uninhabited except for Pak Lahanie's family and consequently is subjected to low levels of terrestrial based pollution (e.g. human waste and industrial and agricultural runoff). However, the island is exposed to adverse weather conditions in both the northeast and southwest monsoons and it is considered one of the best fishing areas for local fishermen. Thus, boats anchor on the reefs of Pulau Durai daily to fish and receive protection from the monsoon winds and waves.

The white sand beaches and fringing reefs at Pulau Durai harbor the largest concentration of sea turtles in the Anambas Islands; both green (Chelonia mydas) and hawksbill (Eretmochelys imbricata) turtles have been observed nesting, feeding and mating (Nichols et al. 2010). In January 2010 Premier Oil, the local government and the majority owners of Pulau Durai agreed to protect the nesting beaches and for the first time in 90 or more years, sea turtles now hatch naturally without being collected and sold in the local fish markets. Because green and hawksbill turtles are endangered worldwide, Biosphere Foundation met with the Bupati (Mayor of the Anambas Islands Regency) to encourage the formulation of a $2 \mathrm{~nm}$ "no-take" fishing zone around Pulau Durai and its neighboring island, Pulau Pahat, which are separated by $6.3 \mathrm{~nm}$. This proposal was adopted in July of 2011 and is now the first marine protected area (MPA) in the Anambas Islands. At the request of the Bupati, and in support of this newly formed MPA, Biosphere Foundation agreed to conduct a study of Pulau Durai's fringing reef to learn about the state of the coral and fish populations. While the details of this MPA and its enforcement need to be worked out, the results of this baseline study will provide valuable information for the implementation of the MPA and its effectiveness in the future.

\section{METHODOLOGY}

This study was conducted from 22 June to 5 July 2011 from the platform of the $34 \mathrm{~m}$ sailing ship, Mir. The ship was moored on a cement mooring at $45 \mathrm{~m}$ depth on the southwest side of Pulau Durai (Fig. 2). The survey team additionally used a small outboard motorboat to travel to and from the study sites.

First, a track around the island along the edge of the reef flat was recorded using a handheld global positioning system (GPS) receiver. A snorkeler was towed by the small boat simultaneously to make visual observations about the ecology of the reefs. Six zones were identified (Fig. 2 and Table 1).

Then, four sites were chosen around the island, generally representing the north, east, south, and west quadrants (Fig. 1). Two $50 \mathrm{~m}$ point intercept transects (PITs) were deployed at each site, one at a shallow (2-4 m) depth and one at a deep $(6-8 \mathrm{~m})$ depth. At $50 \mathrm{~cm}$ intervals along the PIT, the substrate was recorded as live hard coral, dead coral, dead coral rubble or other matter (e.g. broken living coral, soft coral, algae, sand and bare substrate). Within $1 \mathrm{~m}$ along either side of the PIT, the following information was 
recorded: hard coral genera observed; number of live coral recruits (colonies $<4 \mathrm{~cm}$ in diameter); number of crown-of-thorns starfish (Acanthaster planci; COT); and instances of disease and other damage to coral colonies. Fish biomass was recorded along the PIT's using a $2 \mathrm{~m}$ wide belt for fish under $10 \mathrm{~cm}$ long and a $5 \mathrm{~m}$ wide belt for fish over $10 \mathrm{~cm}$ long (Doherty et al. 2011). During the survey period general observations on other live fish seen in the area, fishing boats, and fish sold in the local market were collected.

\section{RESULTS}

The results are presented in the following five sections: Map of Pulau Durai, Site Summary, Coral Substrate, Impacts, and Fish.

\section{Map of Pulau Durai}

The GPS track around the edge of the reef flat of Pulau Durai is shown in Figure 2, and the different ecological zones, recorded A-F, are described in Table 1.

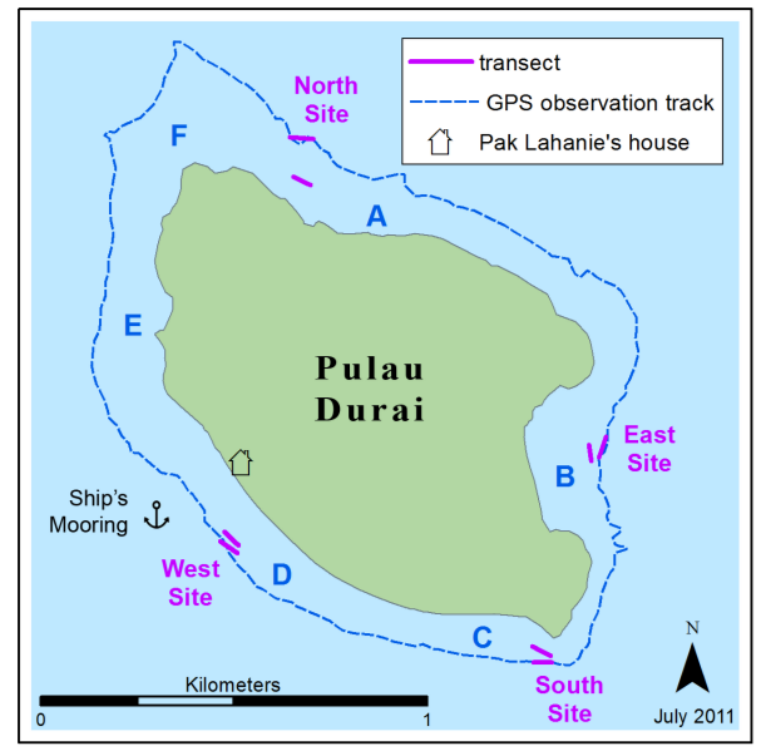

Figure 2. Map of Pulau Durai indicating the site and transect locations, path of the GPS observation track, ecological zones (Table 1), and dwelling location of Durai's one resident family.
Table 1. Ecological zones around Pulau Durai, A-F, that correspond to Figure 2.

\begin{tabular}{|c|l|}
\hline A & $\begin{array}{l}\text { Rocky shoreline with lateral trenches } \\
\text { running offshore and a mix of } \\
\text { healthy, dead and broken coral }\end{array}$ \\
\hline B & $\begin{array}{l}\text { Turtle nesting beach facing east with } \\
\text { live coral reef, coral boulders and } \\
\text { patches of broken or dead coral }\end{array}$ \\
\hline C & $\begin{array}{l}\text { Rocky shoreline facing south with a } \\
\text { beautiful reef composed } \\
\text { predominantly of Acropora table } \\
\text { corals and Porites bommies }\end{array}$ \\
\hline D & $\begin{array}{l}\text { Turtle nesting beach facing } \\
\text { southwest with large areas of coral } \\
\text { rubble, sand and patches of living } \\
\text { coral reef }\end{array}$ \\
\hline E & $\begin{array}{l}\text { Two small bays facing west are } \\
\text { situated across from large coral } \\
\text { boulders up to 2-3 m in diameter, } \\
\text { interspersed with dead coral rubble }\end{array}$ \\
\hline F & Similar to Zone A \\
\hline
\end{tabular}


Site Summary

North Site. (Plate 1) This site had the greatest percentage of live coral cover and greatest number of recruits on the deep transect. Porites and Montipora were the most common coral genera observed. Presence and effects of crown-of-thorns starfish (COTs) were obvious. Around this site is a rocky shoreline and a compact reef exposed to rough weather during the northeast monsoon. Boats were anchoring here for shelter, and fish traps were seen being used.

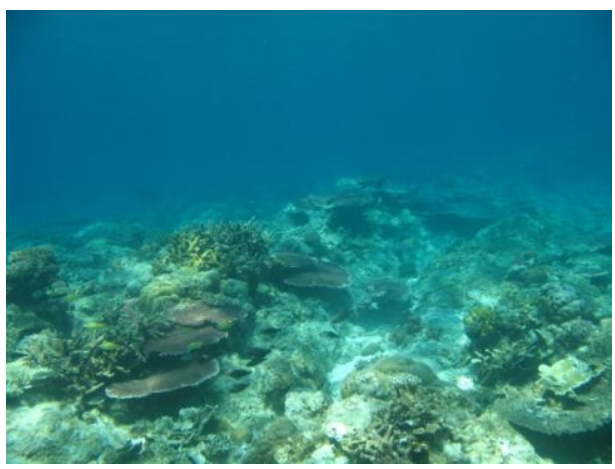

Plate 1. North site.

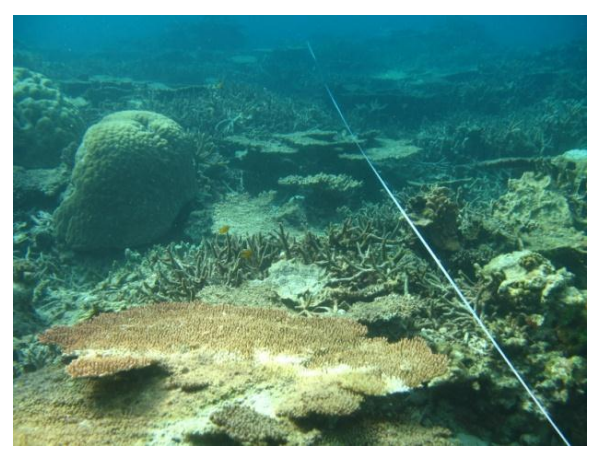

Plate 2. East site.

East Site. (Plate 2) This site had the highest percentage of dead coral and the smallest amount of fish biomass in the shallow transect. It is a sheltered bay where local fishing boats were seen anchoring and men observed to be fishing. An anchor and a fishing net were found close to the transect. Although the fewest COTs were observed on the transects, large numbers of COTs were observed elsewhere in the bay.

South Site. (Plate 3) This site had the greatest number of living Acropora table corals along with the greatest number of COTs and high occurrences of tissue loss observed. The area still had good coral cover as well as the greatest number of fish species. It was the least sheltered and worst site for anchoring. However, a hand line and reel were found close to the transect, indicating that fishing had occurred in the area.

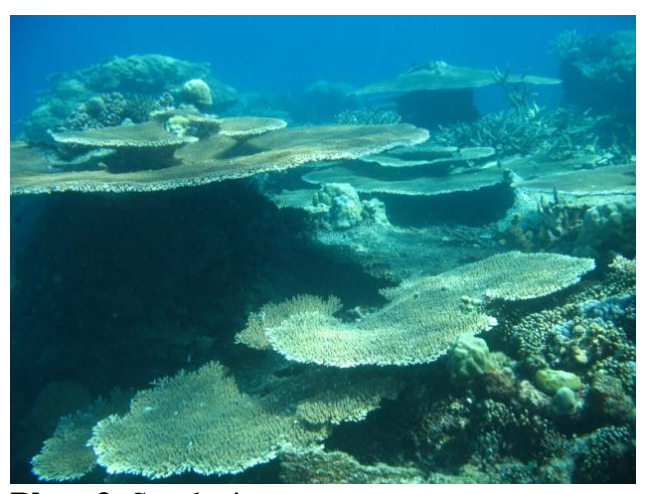

Plate 3. South site.

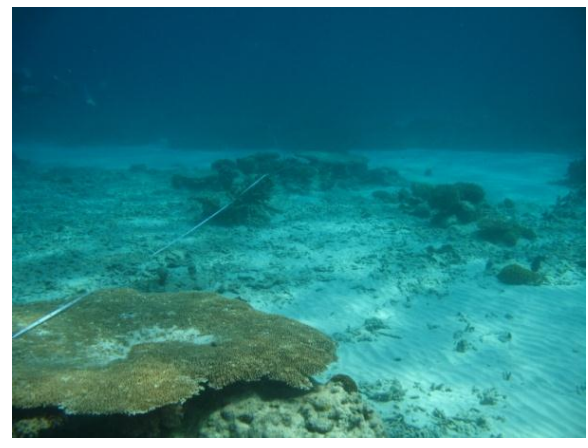

Plate 4. West site.
West Site. (Plate 4) This site had substantially more coral rubble and sand and lower live coral cover than the other sites. Thus, there were fewer COTSs observed here than at the other sites. The area provides shelter to boats during the northeast monsoon and easy beach access year round; thus, there was considerable anchor damage. Old evidence of blast fishing was also observed. Fish species and biomass showed little difference from other sites. 


\section{Coral Substrate}

The PITs showed that the most damaged areas were the east and west sites (Fig. $3)$. The west site appears distinct from the other three sites in terms of its minimal live coral cover $(3 \%)$ and large amount of dead coral rubble $(51 \%)$. The area with the greatest live coral cover was $47 \%$ on the North Deep transect.

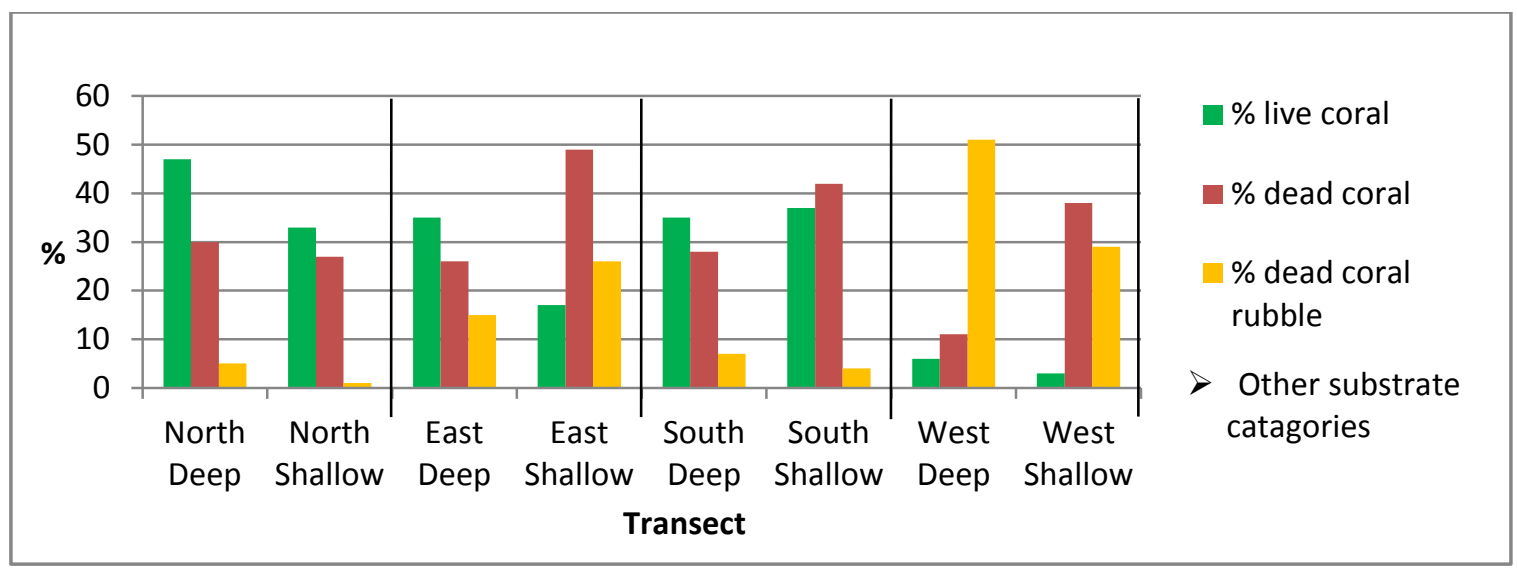

Figure 3. Percentage of live and dead coral cover on substrate.

An average across all sites illustrates that the dominant substrate observed was dead coral (31\%), followed by live coral (26\%), and dead coral rubble (17\%; Fig. 4). "Dead coral" refers to coral that was still intact and thus has probably died recently. "Dead coral rubble" refers to coral that had been broken and turned into rubble, thus indicative of having died earlier than "dead coral."

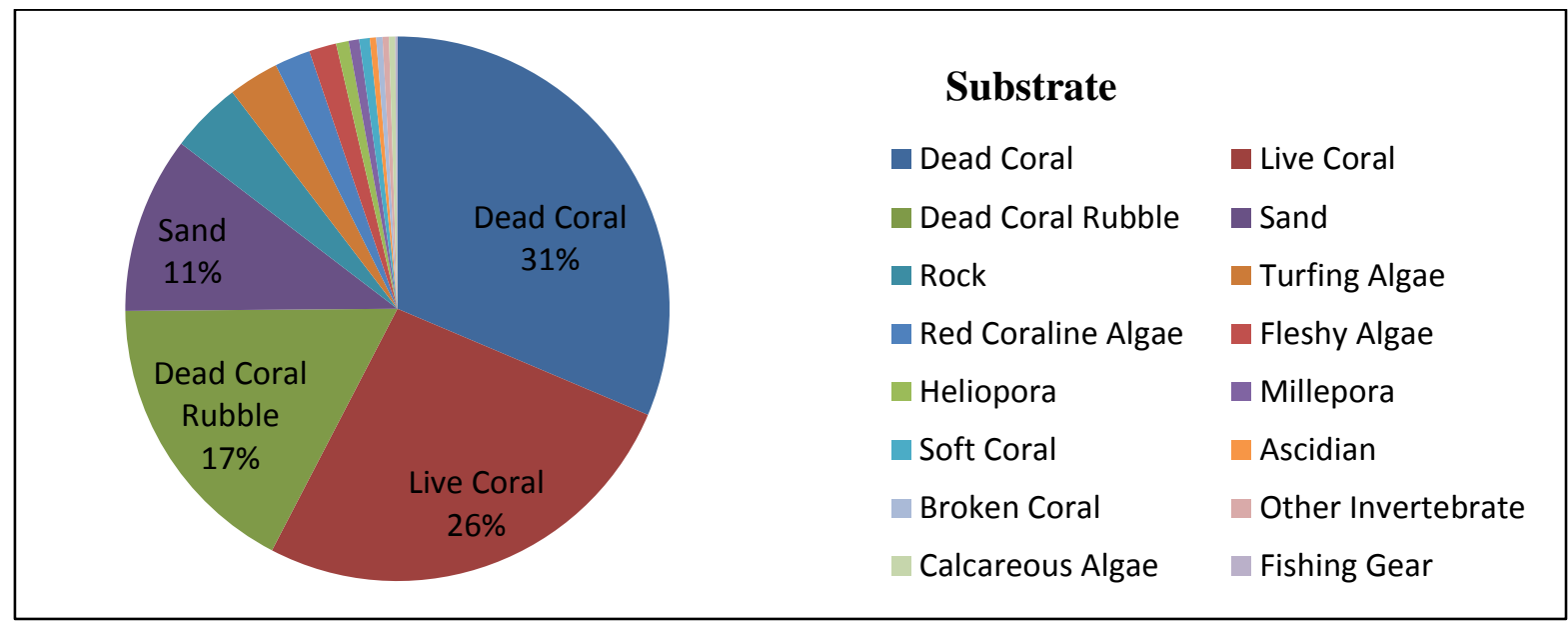

Figure 4. Percentages of substrate composition averaged across all sites. 
Of the dead coral, $78 \%$ had another organism growing on it with $53 \%$ overgrown by red and green turf algae (Fig. 5). Twenty-two percent was bare dead coral substrate.

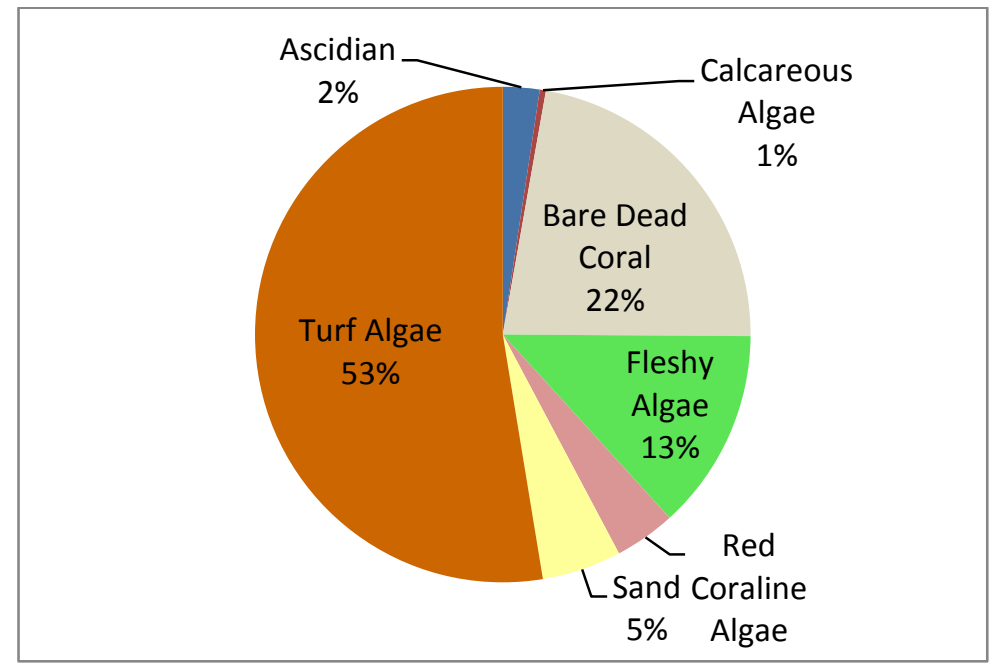

Figure 5. Percentage of matter on top of dead coral substrate.

The number of recruits counted along the transects ranged from a maximum of 30 at the North Deep transect to a minimum of three on both the North Shallow and West Shallow transects (Fig. 6). No clear trend in the number of recruits was obvious among the sites or between depths, although the North Deep transect had the highest number of recruits as well as the highest percentage of live coral cover.

The average number of hard coral genera observed on a transect was 24, with the maximum at 34 on the South Deep transect and minimum at 14 on the West Shallow transect (Fig. 7). In total there were 38 different genera identified across all of the transects at Pulau Durai. At all four sites, the deep transects exhibited a greater number of coral genera than did the shallow transects.

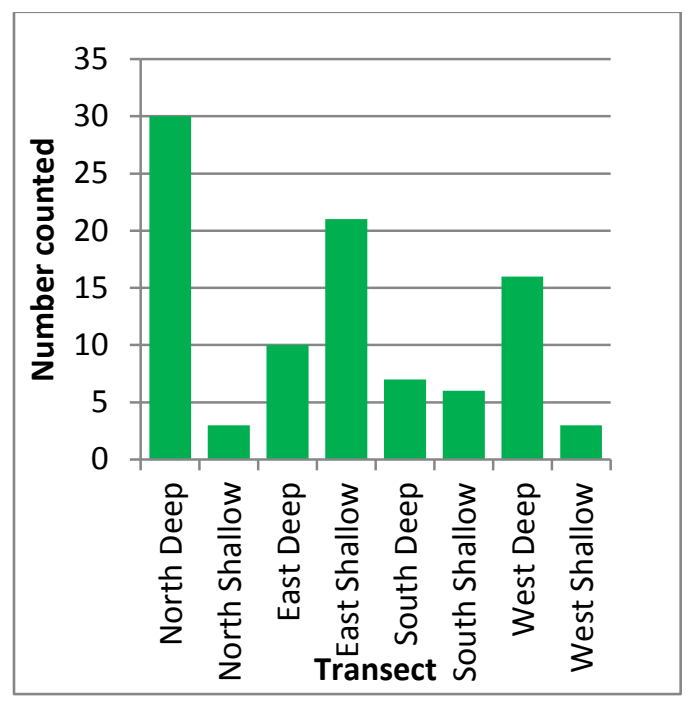

Figure 6. Number of coral recruits counted on each transect.

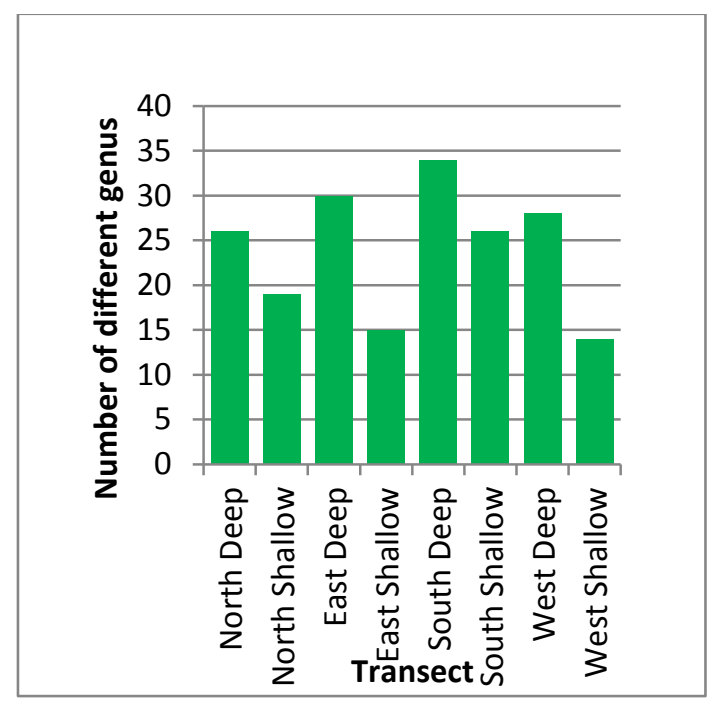

Figure 7. Number of different coral genera observed on each transect. 
At the south site, Acropora was the most abundant genus found on the transects, while at all other sites, either Porites or Montipora was the most abundant (Fig. 8). An average of all sites showed that the most abundant corals were Acropora spp. (37.7\%), Porites spp. (29.2\%), and Montipora spp. (21.1\%; Fig. 9). Each of the other genera present comprised less than 3\% of the live coral coverage.

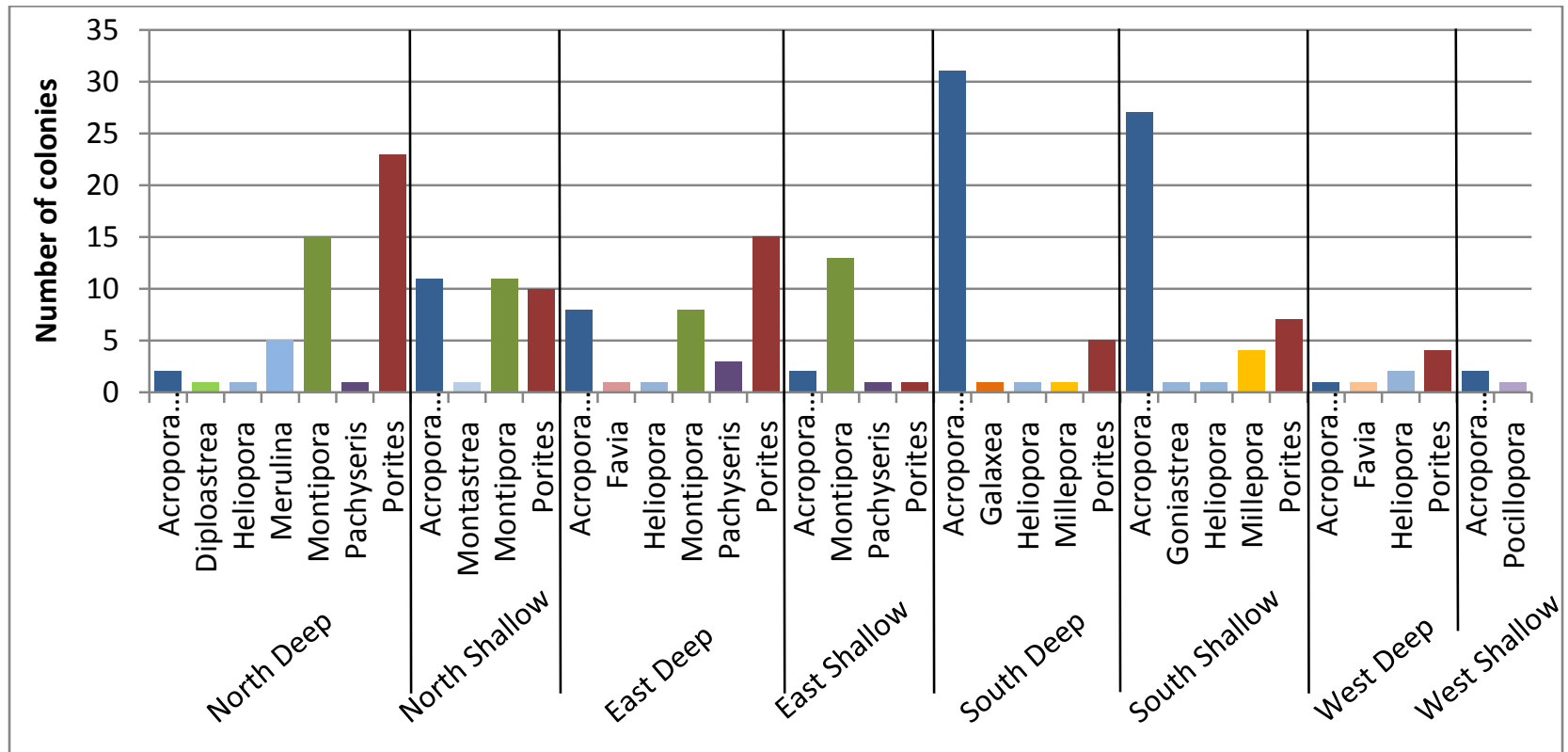

Figure 8. Number of live coral colonies, by genera, observed on each point intercept transect.

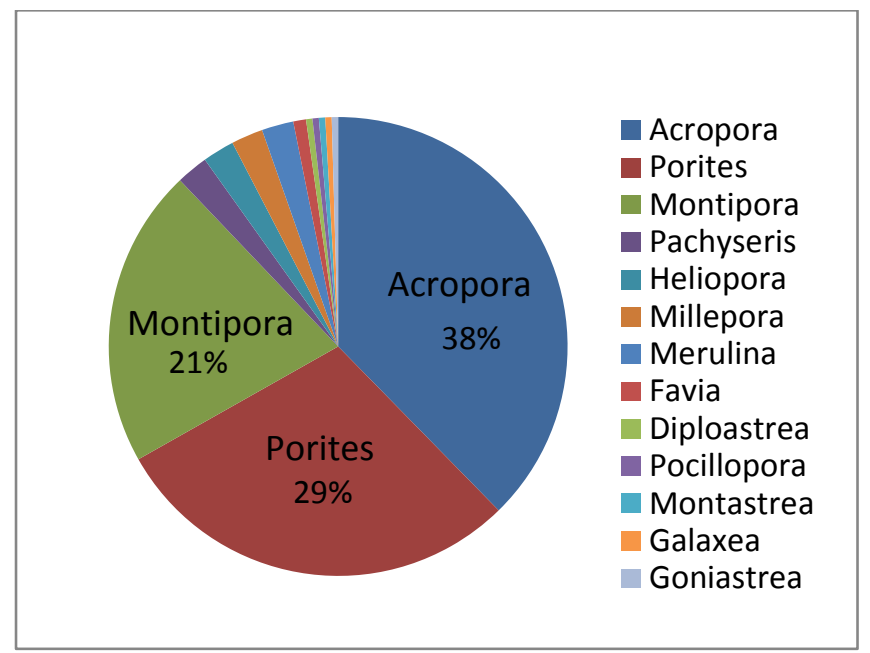

Figure 9. Percentage of each genus observed over all of the point intercept transects.

Impacts

The maximum number of crown-of-thorns starfish (Acanthaster planci; COT) observed on any transect was 15, found at two sites: the North Shallow and South Shallow transects. Both south site transects together had more COTs than any other site (Fig. 10). No COTs were observed on the North Deep and East Deep transects. 


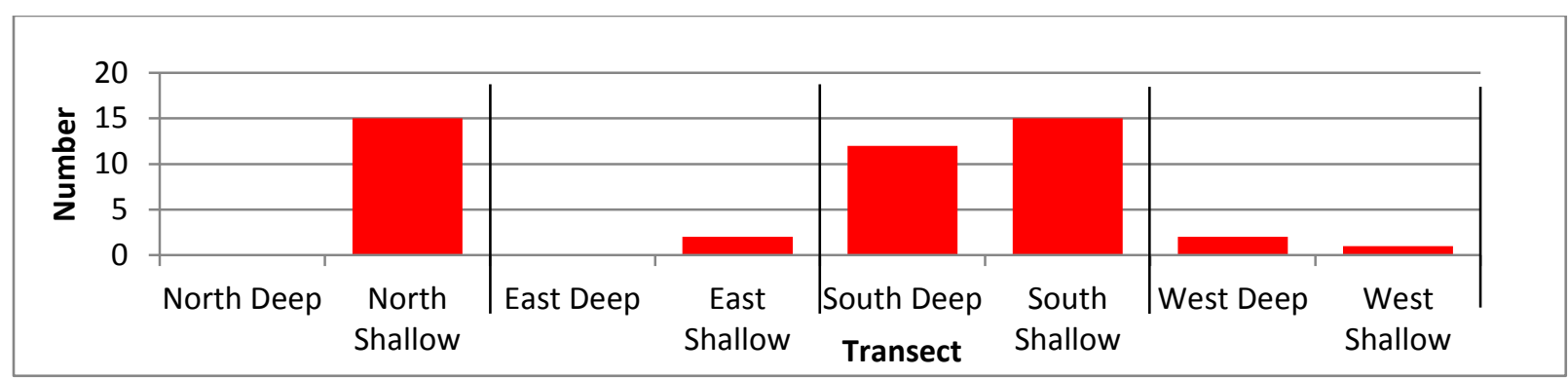

Figure 10. Number of crown-of-thorns starfish counted on each transect.

The most commonly observed recent damage to live coral was areas of white coral skeleton with no tissue ("coral white, with no tissue," Fig. 11). Excluding the two transects where no COTs were seen, the increase in occurrence of COTs coincided with an increase in the number of colonies with instances of this tissue damage. The number of occurrences of disease and other types of tissue damage ("disease and other tissue damage," Fig. 11) followed no recognizable trend.

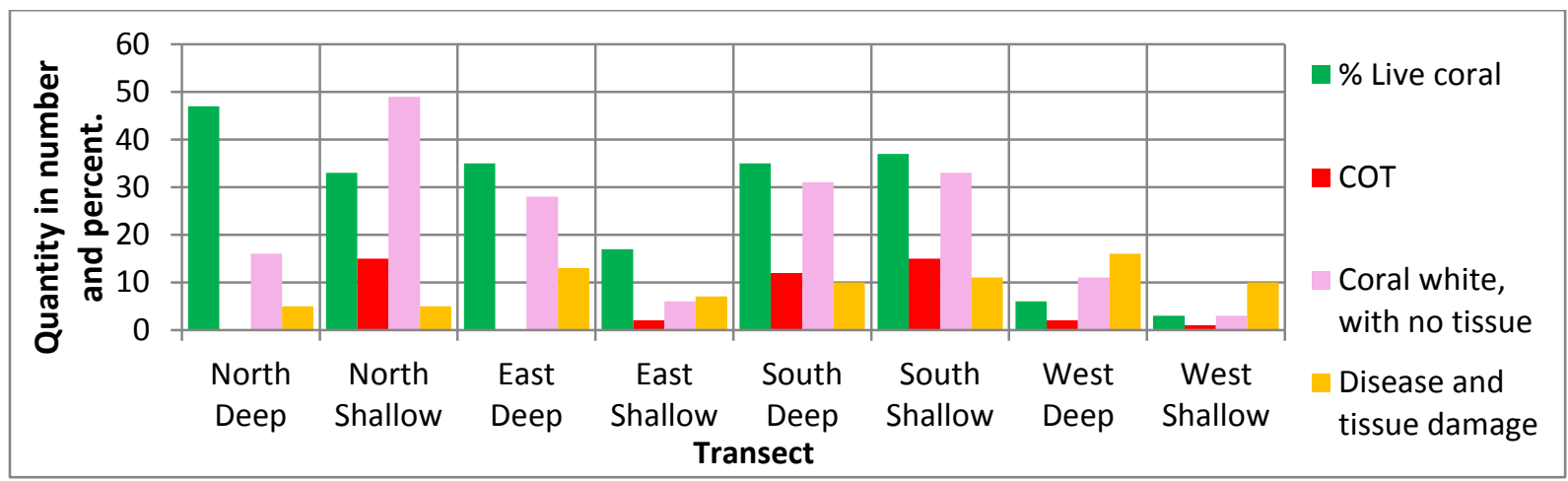

Figure 11. Comparison of percentage of live coral (green), number of crown-of-thorns starfish observed (red), number of coral colonies with tissue loss (pink), and number of colonies with tissue damage and/or disease (yellow).

Fish

Fish Species. The average number of fish species recorded on each transect was 46 . The number of species observed along each transect was relatively constant with a maximum of 54 (South Deep transect) and minimum of 38 (East Shallow and North Shallow transects; Fig. 12). A total of 115 different species of fish were observed at the four sites.

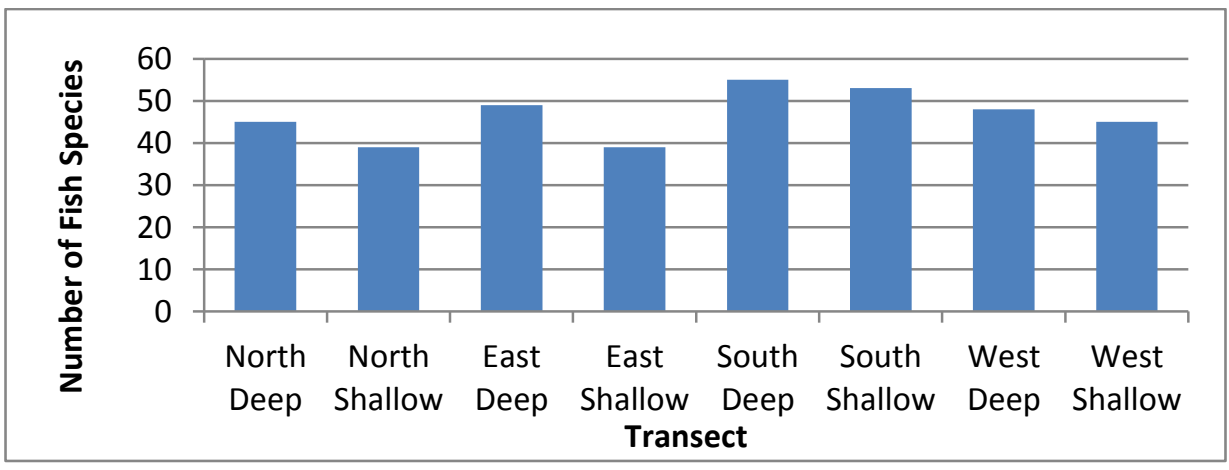

Figure 12. Number of fish species observed on each transect. 
Fish Biomass and Abundance. The fish biomass across all sites was composed predominantly of members of the parrotfish family (Scaridae). The trevally (Carangidae) and damselfish (Pomacentridae) families accounted for the second and third highest biomass values, respectively (Fig. 13). Considering fish abundance, $76 \%$ of fish observed across all sites were of the damselfish family, $10 \%$ were of the wrasse family (Labridae), and $4 \%$ of the parrotfish family (Fig. 14).

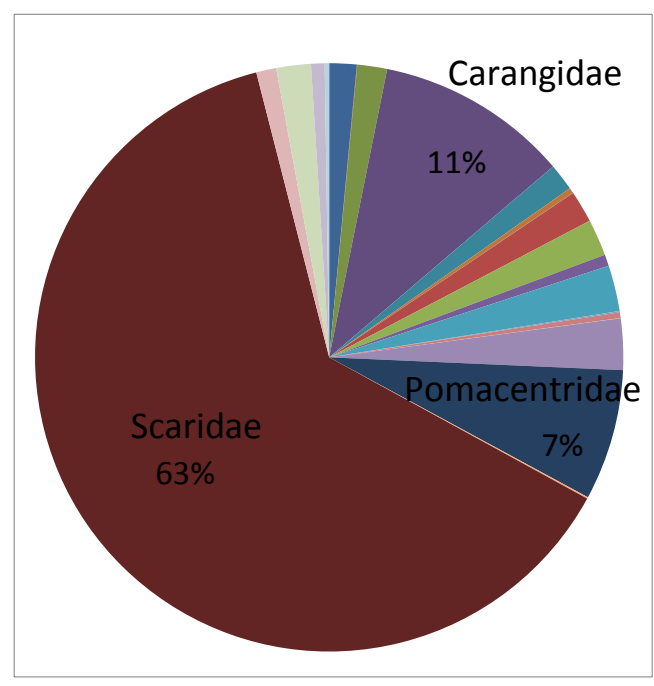

Figure 13. Percentage composition of fish biomass (by family) observed across all sites.

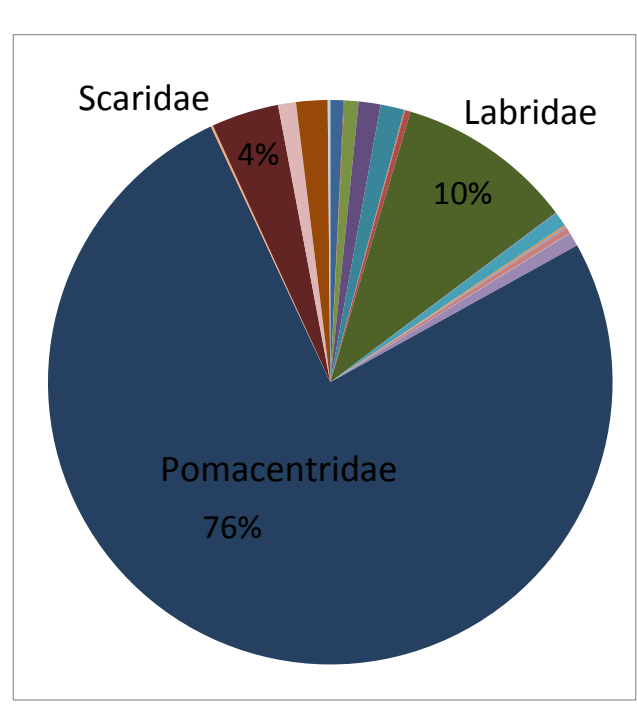

Figure 14. Abundance of fish (by percentage) of families observed across all sites.
ACANTHURIDAE

BALISTIDAE

- CAESIONIDAE

- CARANGIDAE

- CHAETODONTIDAE

DASYATIDAE

- ECHENEIDAE

- KYPHOSIDAE

- LABRIDAE

- LETHRINIDAE

- LUTJANIDAE

MONACANTHIDAE

MULLIDAE

NEMIPTERIDAE

- PLESIOPIDAE

- POMACANTHIDAE

- POMACENTRIDAE

PSEUDOCHROMIDAE

- SCARIDAE

SERRANIDAE

- SIGANIDAE

TETRAODONTIDAE

ZANCLIDAE

The fish biomass was found to be highest at the West Shallow transect $(6755 \mathrm{~kg} / \mathrm{ha})$, substantially higher than at any other transect (Fig. 15). The second and third highest biomass values were $3667 \mathrm{~kg} / \mathrm{ha}$ at the South Deep transect and $1648.4 \mathrm{~kg} / \mathrm{ha}$ at the East Deep transect. The transect with the lowest observed fish biomass $(378 \mathrm{~kg} / \mathrm{ha})$ was the East Shallow transect (Fig. 15). The average across all transects was found to be $2136 \mathrm{~kg} / \mathrm{ha}$.

The fish abundance was found to be highest at the South Shallow transect (51280 fish/ha) and East Deep site transect (39040 fish/ha; Fig. 15). The average abundance across all transects was 23943 fish/ha. The transects with high abundance and low biomass (i.e. South Shallow and East Deep) were dominated by smaller fish, while the transects with high biomass and low abundance (i.e. West Shallow and South Deep) were dominated by larger fish.

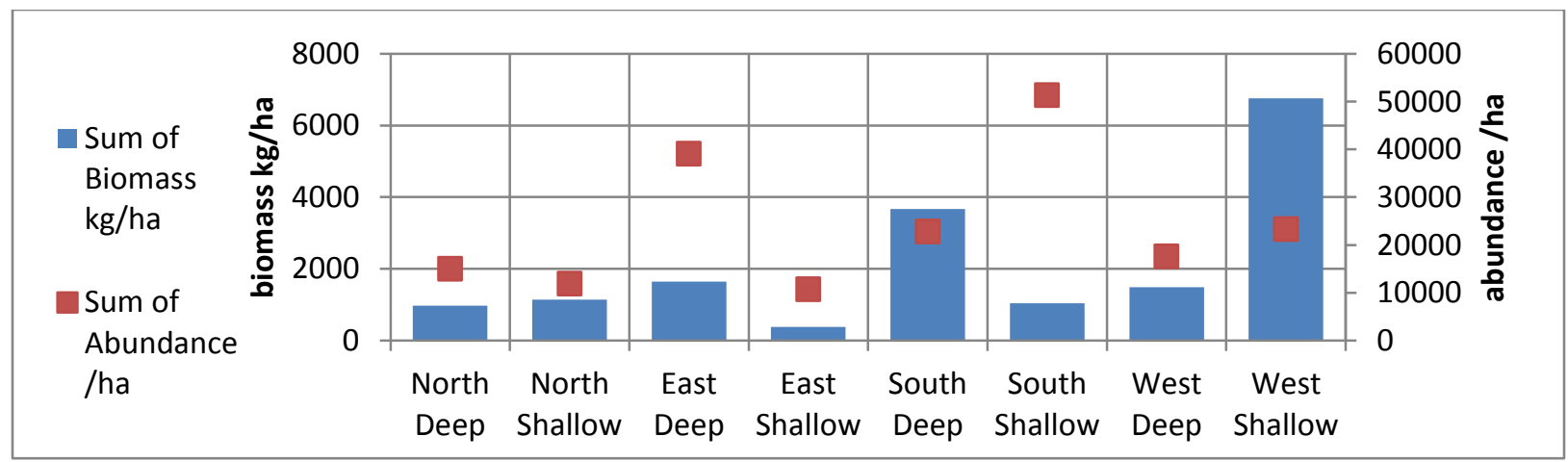

Figure 15. Biomass and abundance of fish on each transect. 
Figure 16 and Figure 17 illustrate the data without including sightings of two critical species. First, eight bumphead parrotfish (Bolbometopon muricatum), which were observed frequently around the island and on all transects except for the East Shallow and South Shallow transects, thus contributing to the lower biomass values recorded on these transects. Secondly, a school of black spotted darts (Trachinotus baillonii) was observed on the South Deep transect briefly, which greatly increased the biomass value for this transect. Because the data from these two species overshadows the other data and skews important information about this reef, we removed the sightings to review the data more closely. While this process fails to affect the order of fish abundance observed across the transects, the highest biomass values are now observed at the South Shallow, South Deep, and East Deep transects which was expected (Fig. 16). Figure 17 illustrates accurately that parrotfish were the most significant contributors to fish biomass, while damselfish, due to their small size and great numbers, were the most abundant and made up the second largest biomass.

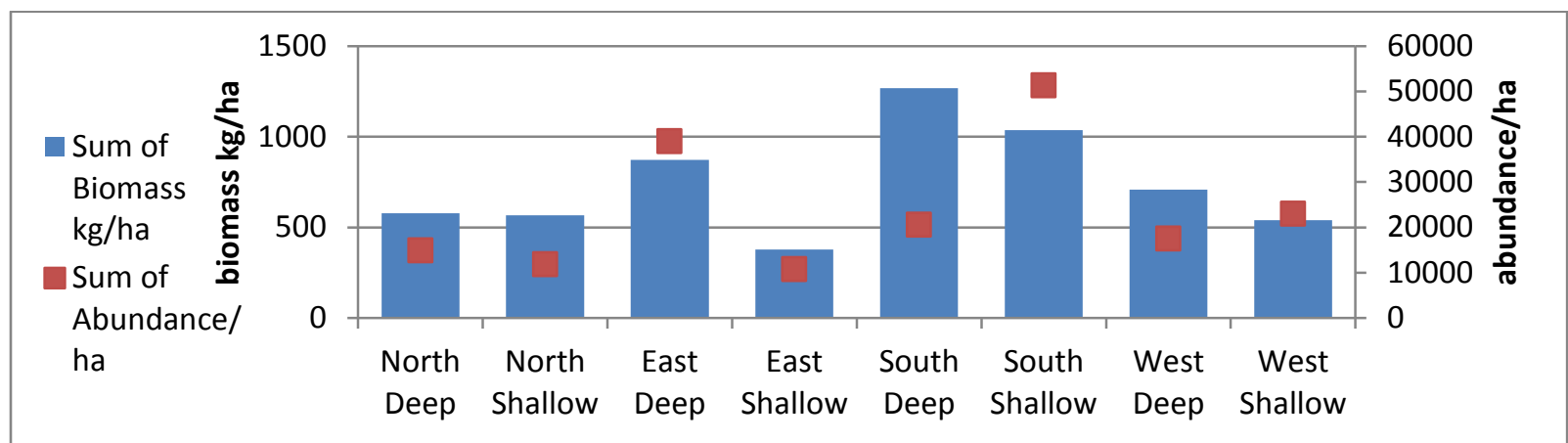

Figure 16. Biomass and abundance of fish on each transect with data from bumphead parrotfish and black spotted darts omitted.

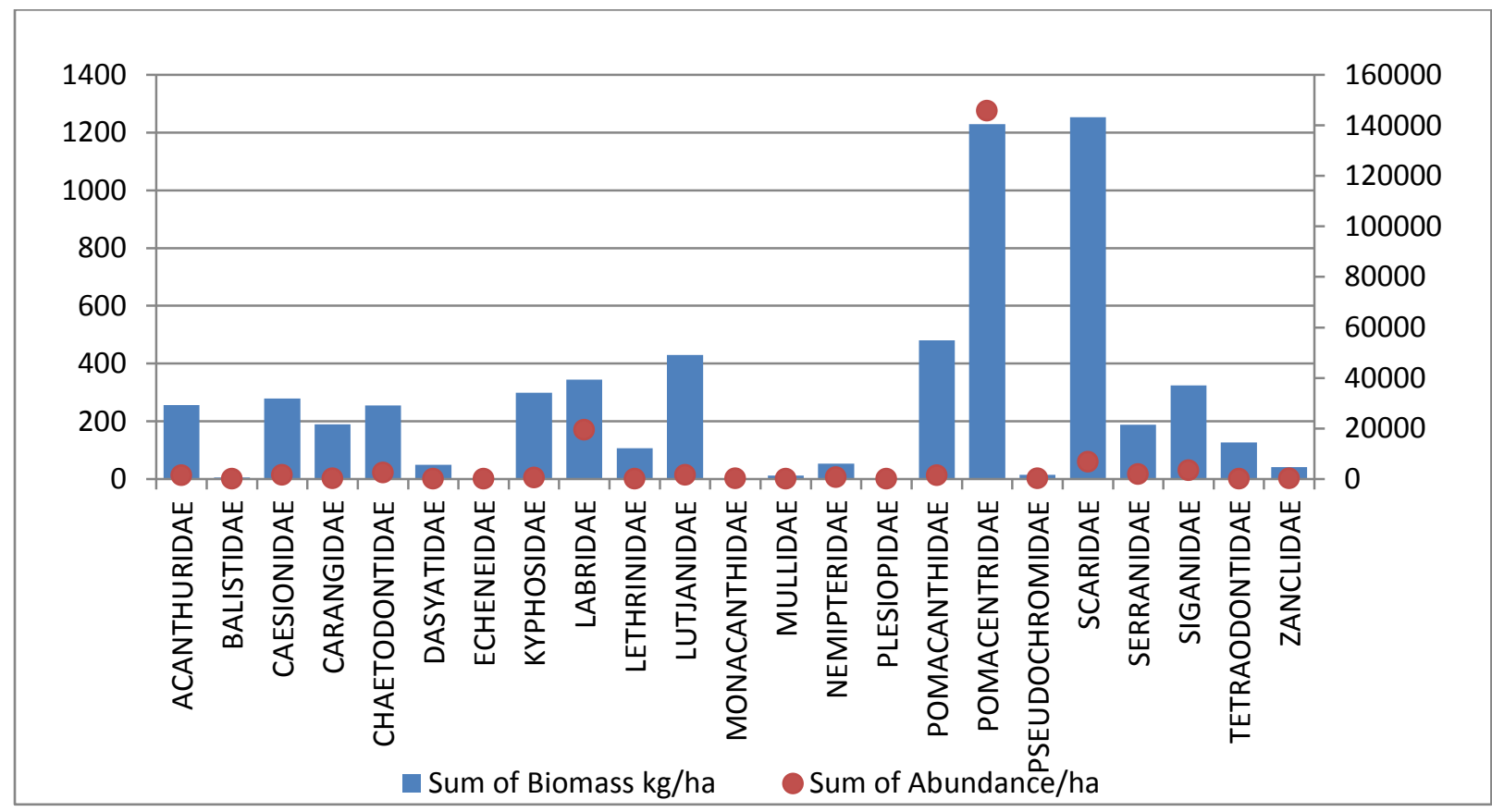

Figure 17. Biomass and abundance of fish, grouped by family, across all sites (data from bumphead parrotfish and black spotted darts omitted). 


\section{DISCUSSION}

Coral Substrate

Substrate composition. The east and west sites have suffered the greatest physical reef damage and have the highest percentage of dead coral rubble (Fig. 3) due to year round boat access and continual damage by anchors. During the present expedition to Pulau Durai (about three weeks' duration in total), boats were often observed anchoring off both of these areas. People were seen visiting the family on Pulau Durai, fishing, harvesting sea turtle eggs (in areas of the island still not protected) and collecting coconuts. The reef to the north of the island also has anchor damage because it is known as a good fishing site and a protected anchorage for boats during the southwest monsoon. Smaller boats anchored close to shore (within $60 \mathrm{~m}$ ) while larger boats anchored farther out, in deeper water. This is not well reflected in our data because neither of our north site transects were located in the area where boats were repeatedly observed anchoring. Finally, the south site is not desirable for anchoring at any time of the year due to the presence of rocks and waves.

Some areas of rubble appear to have also been caused by dynamite fishing, but this activity was not observed at Pulau Durai during the study. Several local residents alleged that dynamiting and cyanide fishing had occurred at Pulau Durai in the past, as well as elsewhere in the Anambas Islands. These findings are consistent with other reported evidence of dynamite fishing in Anambas (Reef Ecology Study Team, 1996; Doherty, 2006).

Recruits. The maximum number of hard coral recruits (30) was observed at the North Deep transect where the coverage of living coral was highest (Fig. 3, Fig. 6).

Observations near (but not on) the west site transects showed areas with new coral growth on an old dead coral rubble field (Plate 5). The new growth on the old damage is a hopeful sign that, if protected from deleterious anthropogenic impacts by the newly established MPA, these recruits may be able to rebuild the damaged reefs of Pulau Durai.

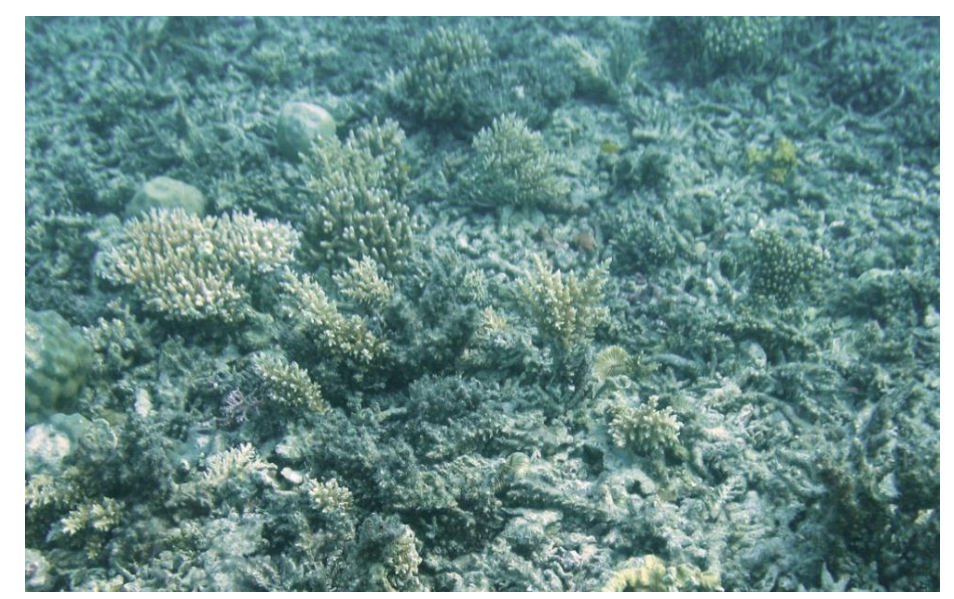

Plate 5. Coral recruits growing on dead coral rubble (near west site).

Genus. Thirty eight different genera of hard coral were recorded over all the transects at Pulau Durai. As a comparison, Scaps et al. (2007) observed between 56 and 68 genre in the Pulisan region, northeast of Sulawesi, within the Coral Triangle of Indonesia. The diversity at Pulau Durai appears low, but it may be typical of this region (further studies will indicate this). 
Impacts and Disease

There is no clear trend in the occurrence of coral disease and tissue damage across the four sites (Fig. 11). The crown-of-thorns starfish (COT) appear to pose the most significant threat to Pulau Durai's live corals at this time, particularly to the Acropora spp. colonies that are numerous at the south site. COTs were observed on at least one transect at all four sites (Fig. 10). The data presented in Figure 11 suggest that instances of coral tissue loss were higher where COTs were observed. This condition is therefore likely due to predation by these corallivores. While no COTs were observed on the North Deep and East Deep transects, numerous corals on these transects exhibited recent tissue loss, suggesting that COTs were active in the area. The length of time that COTs have been present in the area, as well as the condition of the current population, is unknown.

In the literature, proliferation of COTs is mainly attributed to surface water runoff or upwellings adding nutrients to the marine environment (Brodie et al. 2005; Mendonça et al. 2010), and overfishing of predators causing a cascade effect and imbalance at other trophic levels (Dulvy et al. 2004). Pulau Durai is a small island with little runoff and in a shallow sea, so it is more probable that the COTs have become a problem due to over-fishing.

Fish

Fish Species. In a 2002 expedition to the Anambas and Natuna islands, 430 species of fish were identified (Adrim et al. 2004). The present study found 115 species at Pulau Durai. Using the Index of Fish Diversity in the Indo Pacific region (CFDI; Allen and Werner, 2002; Table 2) to judge the species richness of the six most common fish families (Acanthuridae, Chaetodontidae, Labridae, Pomacanthidae, Pomacentridae and Scaridae) the fish species richness around Pulau Durai is "poor” (Table 3).

Table 2. Index of Fish Diversity, CFDI (Allen and Werner, 2002).

\begin{tabular}{|l|l|l|l|}
\hline Relative biodiversity & Single site & Restricted area & Country-region \\
\hline Extraordinary & $>150$ & $>330$ & $>400$ \\
\hline Excellent & $130-149$ & $260-329$ & $330-399$ \\
\hline Good & $100-129$ & $200-259$ & $220-329$ \\
\hline Moderate & $70-99$ & $140-199$ & $160-219$ \\
\hline Poor & $40-69$ & $50-139$ & $80-159$ \\
\hline Very poor & $<40$ & $<50$ & $<80$ \\
\hline
\end{tabular}

Table 3. Number of fish species observed around Pulau Durai in the six most common fish families.

\begin{tabular}{|c|c|}
\hline Site & $\begin{array}{c}\text { Number of species in the 6 } \\
\text { families }\end{array}$ \\
\hline North & 49 \\
\hline East & 43 \\
\hline South & 45 \\
\hline West & 58 \\
\hline $\begin{array}{c}\text { All together } \\
\text { (restricted area) }\end{array}$ & 80 \\
\hline
\end{tabular}


Fish Biomass and Abundance. The higher biomass of parrotfish (Scaridae) and angelfish (Pomacanthidae) that were observed around the island fits with the findings of Campbell and Perdede (2006), illustrating that large biomass of herbivores correlates with an increase in the abundance of dead coral with algae overgrowth as well as the lack of predator fish.

Fish Observations. The only marketable fish seen along the transects were four species of grouper (Serranidae), three species of snapper (Lutjanidae), and three species of trevally (Carangidae). Outside the transects, two blacktip reef sharks (Carcharhinus melanopterus) were seen, three large unidentified pelagic like mackerel, and three milk fish (Chanos chanos) each about $80 \mathrm{~cm}$ long. There were no barracuda (Sphyraenidae) seen. Reef Ecology Study Team (2006) also noted a conspicuous absence of commercially valuable species.

It is possible that over-fishing of valuable fish for human consumption has decimated the fish populations at Pulau Durai (and likely in most areas of the Anambas Islands). The local fish market at Termepah was visited by one of the authors (Milner) in July and on that day, grouper were for sale but none were adults (Plate 6). Several were nearly $10 \mathrm{~cm}$ long and none were longer than $20 \mathrm{~cm}$. Additionally noted were one sailfin snapper (Symphorichthys spilurus), about $40 \mathrm{~cm}$ long (Plate 7); three sharks (Chacharhinidae), each at about $60 \mathrm{~cm}$ long (Plate 8); and one emperor fish (Lethrinidae), about $45 \mathrm{~cm}$ long. Most of the fish at the market were tuna (Scombridae) and trevally (Carangidae), each about $20 \mathrm{~cm}$ long or less (Plate 9).

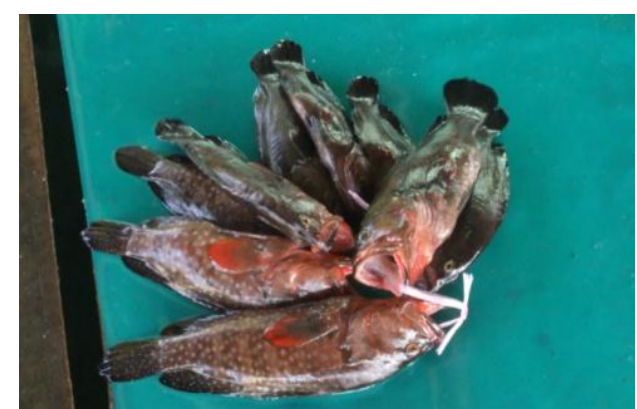

Plate 6. Grouper $<10 \mathrm{~cm}$ in Terempah fish market.

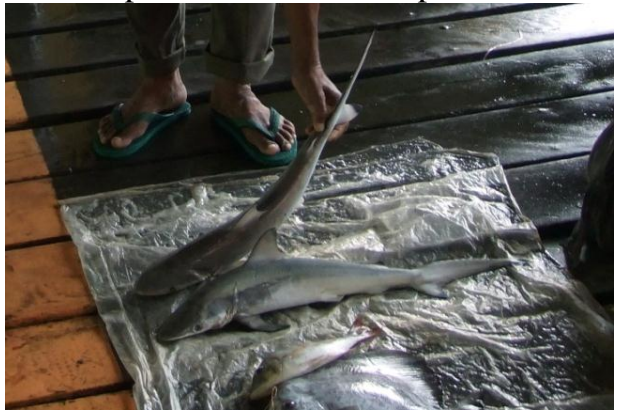

Plate 8. Sharks for sale in Terempah fish market.

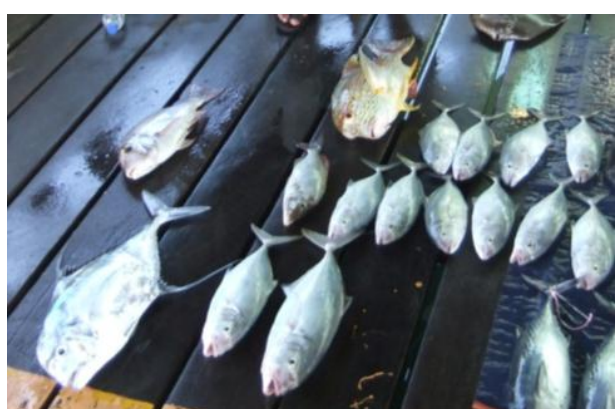

Plate 7. Fish for sale in Terempah fish market.

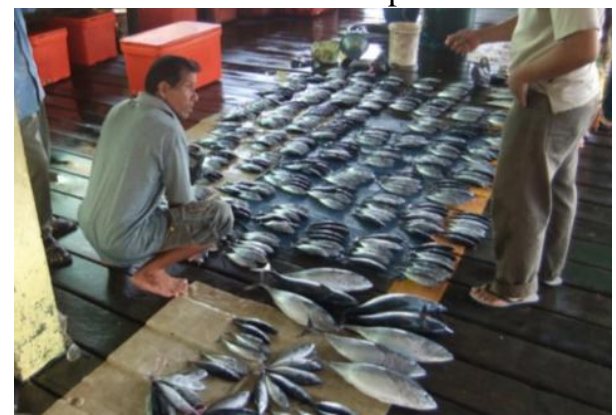

Plate 9. Fish for sale in Terempah fish market.

Throughout the Anambas Islands, the grouper (Epinephalus fuscoguttatus), napoleon wrasse (Cheilunus undulates) and lobster (Panulirus) are raised in live pens to be sold to Hong Kong merchants (Qadar, 2010). The feed sprat come mainly from Tanjung Pinang, Indonesia, but the fishing pressure of feeding the farmed fish is further depleting the already minimal resources in the Anambas Islands. The fishing pressure in the Anambas Islands is clearly greater than the supply available on the reef and does not appear to be sustainable. 


\section{CONCLUSION}

The coral reef around Pulau Durai has been heavily impacted by anthropogenic and biological damage such as boat anchoring, destructive fishing and crown-of-thorns starfish (COT). There are few large predatory and commercially valuable fish left on the reef and there is an increase in fishing pressure due to a growing Anambas Island population, tourism and development in general. Pulau Durai does not have significant land pollution and it already has coral recruits settling on previously destroyed reef, so the reef could potentially recover quickly. With these favourable circumstances, a marine protected area would greatly enhance the future of Durai and have the ability to help restore fisheries in the area if (1) boats are not allowed to anchor on the reef, (2) a "no-take" fishing zone is enforced for both fish and shellfish, (3) no further development is allowed on the island and ideally (4) the COTs are manually removed.

Marine protected areas (MPAs) have proven to be an excellent means of restoring fisheries and marine habitat if the local community is actively involved with the implementation and management of the reserve (Alcala and Russ, 2006; Cinner et al. 2006; McClanahan et al. 2006; Francini-Filho and De Moura, 2008). In these cases, fisheries have recovered in and around MPAs. Of particular relevance is Apo Island in the Philippines where after 18 years of effective no-take management the biomass of surgeonfish (Acanthuridae) and jacks (Carangidae) tripled (Russ et al. 2004); and the Soufrie`re Marine Management Area in St Lucia where, in three years, the combined biomass of five marketable fish families tripled within the reserve and doubled in adjacent areas (Roberts et al. 2001). Thus, for the Anambas Islands, the most important next step is to encourage the local people to support no-take fishing areas in order to restore depleted fish populations and take an active role in sustainable fisheries. Simultaneously, it will be imperative to address the socioeconomic constraints of the fishermen as part of the implementation of the MPA reserve (Agardy et al. 2003; Christie, 2004). Understanding the contributing social and ecological circumstances that led to the degradation of Pulau Durai's reef and fisheries will enhance the ability of the MPA to succeed. Because the fisheries are so depleted it will also be imperative to illuminate potential alternative sources of income for local fisherman in order to take the pressure off fishing while creating an effective network of MPAs throughout the Anambas Islands.

Nevertheless, the declaration of Pulau Durai and Pulau Pahat as a MPA by the government of Anambas is a positive step toward this overall goal, and should be supported by international and local efforts to ensure its success. Towards this end, Biosphere Foundation will return annually to provide consultation and to implement education programs to raise awareness among the people regarding the effectiveness of MPAs at restoring fisheries and the health of coral reefs.

\section{ACKNOWLEDGMENTS}

We wish to honor the local government, the people of Anambas Islands including Durai Island's caretaker Pak Lahanie, and the people of Indonesia for their collaboration, hard work and willingness to embrace conservation at Pulau Durai. Ibu Nina Marliana joined us in 2009 with Premier Oil and continued in 2011 to guide us locally while representing Biosfir Indonesia (Biosphere Foundation's Indonesia-based projects). Captain of Mir, Mark Van Thillo, Educational Officer, Rogerio Soares, and Andrew Fox provided support to the science team daily and Dr. Wallace J. Nichols who continues to inspire the sea turtle protection program. Finally, 
we wish to thank Raffles Marina, the Roy A. Hunt Family Foundation, the Burke Family, Threshold Foundation, Project Aware, Biosphere Society Singapore, Beyond Boundaries and Premier Oil for supporting the work of Biosphere Foundation in the Anambas Islands over the past few years.

\section{REFERENCES}

Adrim, M., I. Chen, Z. Chen, K.K.P. Lim, H.H. Tan, Y. Yusof, and Z. Jaafar.

2004. Marine Fishes Recorded from the Anambas and Natuna Islands, South China Sea. . The Raffles Bulletin of Zoology. supplement no. 11: 117-130.

Agardy, T., P. Bridgewater, M.P. Crosby, J. Day, P.K. Dayton, R. Kenchington, D. Laffoley,

P.K. McConney, P.A. Murray, J.E. Parks, and L. Peau.

2003. Dangerous targets? Unresolved issues and ideological clashes around marine protected areas. Aquatic Conservation: Marine and freshwater ecosystems. 13: 353367.

Alcala, A.C., and G.R. Russ.

2006. No-take marine reserves and reef fisheries management in the Philipines: A new people power revolution. Royal Sweedish Acadamy of Sciences. 35: 245-254.

Allen, G.R., and T.B. Werner.

2002. Coral reef fish assessment in the 'coral triangle' of southeastern Asia. Environmental Biology of Fishes, 65: 209-214.

Brodie, J., K. Fabricius, G. Death, and K. Okaji.

2005. Are increased nutrient inputs responsible for more outbreaks of crown-of-thorns starfish? An appraisal of the evidence. Marine Pollution Bulletin. 51: 266-278.

Campbell, S.J., and S.T. Pardede.

2006. Reef fish structure and cascading effects in response to artisanal fishing pressure. Fisheries Research. 79: 75-83.

Christie, $\mathrm{P}$.

2004. Marine protected areas as bilogical successes and social failures in Southeast Asia. American Fisheries Society Symposium. 42: 155-164.

Cinner, J.E., M.J. Marnare, T.R. McClanahan, and G.R. Almany.

2006. Periodic closures as adaptive coral reef management in the Indo-Pacific. Ecology and Society. 11: 31-50.

Doherty, O. on behalf of Planetary Coral Reef Foundation.

2006. Anambas Islands Observational Report.

Doherty, O., A. Alling, C. Milner, S. Campbell, S. Pardede, T. Kartawijaya, P. Dustan, J. Sartin, and D. Kartika.

2011. Report on Menjangan Island's Coral Reef: A Bali Barat National Park Marine Protected Area. In Press.

Dulvy, N.K., R.P. Freckleton, and N.V.C. Polunin.

2004. Coral reef cascades and the indirect effects of predator removal by exploitation. Ecology Letters. 7: 410-416.

Francini-Filho, R. B., and R.L. De Moura,

2008. Dynamics of fish assemblages on coral reefs subjected to different management regimes in the Abrolhos Bank, eastern Brazil. Aquatic Conservation: Marine and Freshwater Ecosystems. 18: 1166-1179. 
McClanahan, T. R., N.A.J. Graham, J.M. Calnan, and M.A. MacNeil.

2007. Toward Pristine Biomass: Reef Fish Recovery In Coral Reef Marine Protected Areas in Kenya. Ecological Applications. 17: 1055-1067.

McClanahan, T. R., E. Verheij, and J. Maina.

2006. Comparing the management effectiveness of a marine park and a multiple-use collaborative fisheries management area in East Africa. Aquatic Conservation: Marine and Freshwater Ecosystems. 16: 147-165.

Mendonça, V. M., M. Al Jabri, M.I. Al Ajmi, M. Al Muharrami, M. Al Areimi, and H.A. Al Aghbari.

2010. Persistent and Expanding Population Outbreaks of the Corallivorous Starfish Acanthaster planci in the Northwestern Indian Ocean: Are They Really a Consequence of Unsustainable Starfish Predator Removal through Overfishing in Coral Reefs, or a Response to a Changing Environment? Zoological Studies. 49: 108123.

Ng, P. K. L., A.G. Ilahude, N. Sivasothi, and D.C.J. Yeo.

2004a. Expedition Anambas; An overview of the Scientific Marine Exploration of the Anambas and Natuna Archipeligo, 11-22 March 2002. The Raffles Bulletin of Zoology. 11: 1-17.

Ng, P. K. L., D. Wowor, and D.C.J. Yeo, eds.

2004b. Scientific results of the Anambas expedition 2002. The Raffles Bulletin of Zoology. supplement, 11.

Nichols, J., N. Marliana, Pak Lahani, Y. Kholison, M. Tanjung, A. Alling, and M. Van Thillo.

2010. Hope for Sea Turtles in the Anambas Islands, Indonesia. Presented at the 31st Annual International Symposium on Sea Turtle Biology and Conservation in San Diego, CA.

Qadar, S. A.

2010. Anambas: the Exotic Islands.: Directorate of Small Island Empowerment, Directorate General of Marine Coastal and Small Islands, Ministry of Marine Affairs and Fisheries, in association with PT. Aliansi Pentamitra.

Reef Ecology Study Team

1996. Expedition to Pulau Langor, Anambas Islands, Indonesia. 25 May to 2 June 1996. Report submitted to Francis Lee, President of Raffles Marina.

Roberts, C. M., J.A. Bohnsack, F. Gell, J.P. Hawkins, and R. Goodridge.

2001. Effects of marine reserves on adjacent fisheries. Science. 294: 1920-1923.

Russ, G. R., A.C. Alcala, A.P. Maypa, H.P. Calumpong, and A.T. White.

2004. Marine reserve benefits local fisheries. Ecological Applications. 14: 597-606.

Scaps, P., V. Denis, S. Berhimpon, and F. Runtukahu.

2007. Zooxanthelate scleractinian corals of the northern coast of Sulawesi. Atoll Research Bulletin. 553. 